\title{
Determinant Moments for the Design Management Occurrence in Fashion Industry
}

\author{
LIBÂNIO, Cláudia de Souza ${ }^{a^{*}} ;$ AMARAL, Fernando Gonçalves ${ }^{b}$ and MIGOWSKI, Sérgio Almeida ${ }^{c}$ \\ ${ }^{a}$ Universidade Federal de Ciências da Saúde de Porto Alegre/UFCSPA \\ ${ }^{\mathrm{b}}$ Universidade Federal do Rio Grande do Sul/UFRGS \\ ${ }^{c}$ Instituto Federal do Rio Grande do Sul/IFRS \\ * Corresponding author e-mail: clasl@terra.com.br \\ doi: 10.21606/dma.2017.279
}

\begin{abstract}
Design management has occupied a privileged place in debates related to the field of design and innovation in fashion industry. The apparel industry, in particular, presents a dynamic character, requiring constant updates on raw materials, changes in colors and textures, innovations and new product launches to follow trends in this industry. It becomes clear the need to understand design as a strategic element as well as using the design management in organizations. Therefore, this paper aims to systematize the process of product development, identifying the players and their competencies involved and mapping the determinant moments for the design management occurrence in context analysis. The methodology used was a systematic literature review and a multiple case study. As results, players involved have been identified as well the product development process and the intervenient factors in design management of companies imbricated in the apparel industry. We also have identified determinant moments for the occurrence of design management, throughout the product development process.
\end{abstract}

Design management; product development process; teamwork; decision making

\section{Introduction}

Many organizations direct their financial resources to products, services and research development in order to create and innovate, differentiating their portfolios from its competitors. In this way, these organizations have been showing interest in investing in design, perceiving it as a vehicle for change and a strong ally for innovation. However, for achieve the expected return on investment and for design to be a vehicle for change, design needs to be seen as a strategic element, and to be understood as a process. Design is part of the objectives of the companies, being thought in the initial phase of the development of strategies, guidelines and portfolio management, permeating all levels of the company activities. With this, in addition to the other organization activities, the 
company starts to carry out the activity of design management. Borja de Mozota (2003, p.71) defines design management as "the implementation of design as a formal program of activity within a corporation by communicating the relevance of design to long-term corporate goals and coordinating design resources at all levels of corporate activity to achieve the objectives of the corporation."

However, in order to design integrates the organizational environment and be part of the company's goals, these organizations know who the players and coworkers are involved in the product development process. In addition, organizations need to define what competencies are required at each stage of the product development process to better articulate their actors in an efficient and effective way, aiming at the optimization of their resources. The garment industry, in particular, has many actors involved throughout the product development process, with different competencies and expertise. In this way, design management can help organizations: communicate the relevance of design, empower design as a vehicle for change, and also coordinate design resources at all levels of organizational activities. Borja de Mozota (2003) emphasizes that design management has two main goals: to form partners-managers and designers and to develop methods to integrate design in the organizational environment.

Thus, this article aims to systematize the process of product development, identifying players and their competencies involved and mapping the determinant moments for the design management occurrence in context analysis. Thus, the question presented here is: what are the determinant moments in the product development process for the design management to occur and to foster design as a vehicle for change, who are involved and what are their competencies in this process?

\section{Literature Review}

Constantly, ways to systematize and understand the design management in companies are developed. Portuguese Design Centre - PDC (1997) starts the process of development of design projects by the stage called as recognition or impulse, described as the right time to act, that is, the recognition of potential opportunities. The next stage is the analysis. This step is strongly related to the previous one because, starting from the opportunity identified, a strategy can be drawn towards the solution. The third phase is the definition/decision, where the product in an elemental form is defined in relation to the company and its market. The exploration phase consists in learning how to make the product to be developed. The fifth step is the selection, where after the evaluation of all options developed, one is chosen. The development phase refers to detailing what will be effectively developed. Later, there is a stricter detailing, in the phase of specification. Lastly, there is the phase for launching the product in the market.

Other model addressed is the one from Bruce et al. (1999), entitled framework for design management, which exposes a sequence of steps for the design management to occur. The first step is called taking action, where the design manager creates the initial concept of the project. The second moment is evaluating the concept followed by their development. Next, there is the research made by the designer. The briefing and their validation form the following moments. Subsequently, there are the stages called mock up and mock-ups (reworked and re-evaluated), which present the moments from the development to the prototype validation. After the initial version of the developed prototype, it is thought, experimented, evaluated, remade, and re-evaluated until the final approval. After the step of experimental production, next comes the total production of the products. After the step of the production, there are the launching promotion and the evaluation of the launching of the products in the market. Once the process is concluded, there is step of removing the product from the market.

Focusing on the apparel industry, the literature presents the models by Treptow (2007), McKelvey and Munslow (2008) and Renfrew and Renfrew (2009). Treptow (2007) mentions the phase for planning, which consists in the initial step of the author's proposition. In the next phase, there is the elaboration of the collection's timetable, followed by the definition of the parameters and 
dimension (size) of the collection. The fifth step consists in researching trends. Subsequently, the briefing and the concept of the collection are defined. The development is the next step of the process, concerning the moments of inspiration, study of colours, fabrics and trimmings, drawings, modelling, prototyping, technical specifications, sale price definition, and development of showcase. Next, there is the step of launching and release, followed by sale and production. Afterwards, the deliveries are prepared until the last step, which consists in feedback meeting.

McKelvey and Munslow (2008) suggest that this process comes from the analysis of the brief, by identifying innovative opportunities. From this analysis, two researches can be carried out: inspiration research and direction research. The inspiration research refers to the concepts and personal inspirations. The direction research refers to the prediction of fashion and trends, comparative and directional reports from the retail, reports from fairs, and market researches. These two researches move to the following step, which is the process of the very design. This process includes the definition of colours, silhouettes, proportions, fabric, impressions, patterns, textures, samples, and assembly. The prototyping is the next step, which is the flat cut, patterning, modelling, structuring and defining the adornments and accessories. Next, the collection is defined, where the garments and accessories are put together for a decision to be made. Promotion is the final step, when the advertising pieces, the photographic style, and the creation of the portfolio of the collection are defined.

According to Renfrew and Renfrew (2009), the process begins by researching the market. Second, the consumer is identified, followed by research and development. Third, the following steps are included: briefing for the prototyping team, final costs, and production requests. Next, there is stage of presenting the collection, which consists in preparing the fashion show, the show itself, after the show, in reviewing the applications, in confirming the products for delivery, and defining the final costs. The authors highlight that the process is not finite and, when the last step is finished, it begins again. However, by observing the models listed previously, gaps are seen in different steps of each model.

\section{Research Methods}

The present study conducted a bibliographic research by developing a systematic review of literature as well as an exploratory research with a qualitative approach while using in-depth interviews. These research techniques were important to define the determinant moment for the design management to occur in apparel industry companies. Next, the steps of the methodology used in this study are described.

\subsection{Performance of the systematic literature review}

Firstly, a systematic literature review was applied, whose goals of exploratory character were developed, aiming to identify connections and interrelationships among the topics of design management, players and their competencies. The following methodologies were adopted: Anderson et al. (2003), Alderson et al. (2004) and Biolchini et al. (2007) for the sequence of the methodological steps, as it is shown in Table 1.

The systematic literature review was done in scientific papers in portals such as: Science Direct, Web of Knowledge, and Wiley to search for articles, by using the keywords 'design management' and 'competenc*'. Articles published in periodicals addressing competences and their relationships with design management were researched. The period used for the search comprised the journal articles published until the end of 2015. 1172 articles were collected in specific portals, but only 38 studies were selected. 1134 studies were discarded because the comprehensiveness of meanings of the word design (draw, project or methodology). For example, the word 'design' is often used in the term 'design research', referring to methodological construction. Bibliographies of these studies were analyzed, identifying the existence of another study. From this, 39 articles discussing this topic were selected. The articles selected were read in full, and information was tabled and analysed. 
Table 1 Steps of the systematic review of the literature.

\begin{tabular}{|l|l|l|}
\hline Anderson et al. (2003) & Alderson et al. (2004) & Biolchini et al. (2007) \\
\hline 1) Develop a conceptual framework to & 1) Develop a protocol; & 1) Ask the question; \\
organize, group, and select the & 2) Formulate the problem; & 2) Select the sources; \\
research; & 3) Find and select studies for & 3) Select the studies; \\
2) Systematic research, data recovery; & the review; & 4) Extracts of the information; \\
3) Evaluate the quality and summarize & 4) Assess the quality of the & 5) Results. \\
the effectiveness of the evidence; & studies; \\
4) Summarize information on other & 5) Collect data; \\
evidence (applicability, economy, & 6) Analyse and present the \\
other effects and barriers to & results; \\
implementation); & 7) Interpret the results; \\
5) Identify and summarize the & 8) Improve and update the & \\
research gaps. & reviews. & \\
\hline
\end{tabular}

Source: Adapted from Anderson et al. (2003), Alderson et al. (2004), Biolchini et al. (2007).

This procedure mapped the current state of the topic addressed here, as well as the understanding of design management related to the individual, collective, and organizational competences. With this analysis, concepts related to design management and competencies also emerged, such as: learning, skills, resources, knowledge, value, interactions, communication, collaboration, market context, organizational culture, organizational structure, work processes, and stakeholders involved.

\subsection{Proposition of the determinant moments for the design management to occur}

In a second moment, a research exploratory, qualitative was developed (Malhotra, 2012), by studying multiple cases and proposing in-depth interviews. By using two semi-structured scripts, interviews were conducted with four experts in fashion design and ten design professionals working in the apparel industry companies in Southern Brazil. The sample was limited to 14 respondents because of the recurrence of data of the interviews. Regarding the qualitative research, Malhotra (2012) states that this is a non-structured, exploratory research methodology, made from small samples, enabling a better perception and understanding of the problem at hand. The results of the interviews were analysed using the content analysis approach (Bardin, 2005). Therefore, a product development process based on design management was analysed, identifying the actor and their competencies involved in each step of the process. The findings of the research also pointed to identify the determinant moment for the design management to occur and to foster design as a vehicle for change, in apparel industry companies.

\subsection{Checking, evaluation, and finalization of the determinant moments for the design management to occur in apparel industry companies}

In order to check the proposition of the decisive moments of design management, a group of experts was assembled, which was composed of three designers working in companies belonging to the apparel industry and two experts in fashion design. The interviews with five experts were recorded and transcribed. The data were tabled and analysed by using content analysis approach (Bardin, 2005). A direct approach was used in the interviews, and the data were obtained through primary sources. To ensure the anonymity of the five respondents, they are identified in this study as interviewee 1 (I1), interviewee 2 (I2), interviewee 3 (I3), interviewee 4 (I4), and interviewee 5 (I5).

Throughout the interviews, the proposition of the decisive movements was presented to the experts, and they were free to analyse, criticize, and suggest changes and/or propose new ideas in order to verify the structure and evaluate the applicability of this tool. After the interviews were concluded, the data were analysed and considered to change and finally assemble the proposition of the determinant moments. 


\section{Proposition}

To prepare this proposition, we started from a systematic review of literature on design management and skills were performed to the search in the literature for design management models (specific of the apparel industry), and a qualitative research with four experts and ten design professionals. From the analyses carried out, the following were developed: a comparative table with the models found in the literature that were applicable to the study, a drawing of the process of development of the product resulting from the multi-case study, and the identification of key stakeholders in each stage of this process. The analyses of the data from bibliographical research and the in-depth interviews made it possible also to identify the decisive moments for the design management to occur throughout this process.

\subsection{Systematic literature review}

Thirty-nine articles dealing with the topic of design management and skills were selected, which enabled the mapping of the current scenario of research on skills in design management, highlighting inter-relations and possible connections between the topics and other aspects identified.

The study identified an overview of the articles analysed, while evidencing an advance in the publication over time and locating the research centres about the addressed topic over the world. It is clear a larger number of publications about this topic in 2005 and 2007 and a concentration of research centres in Europe.

An analysis of the links between design management competencies and the identification of concepts related to competencies that can help in structuring and integrating design teams and their partners about the occurrence and development of design management in enterprises have been developed. It appeared that the competencies strongly pervade the concept of design management and when articulated, they can assist in structuring and integrating design teams and partners involved in the design management.

The studies selected address essential, individual, collective, organizational, central, collaborative, and strategic competencies, as well as the characterization, creation, development, performance, management, allocation, and connections of those. From the analysis of the collected studies, it could be concluded also that these competencies occur at the individual, collective, and organizational level and when articulated to design management, they collaborate to achieve sustainable competitive advantage of the organizations.

Other aspects related to the competences in design management were also identified, such as: learning, skills, resources, knowledge, value, interactions, communication, collaboration, market context, organizational culture, organizational structure, work processes, and stakeholders involved. These concepts present relationships and enable connections and articulations with the competences in the design management.

\subsection{Models from the literature}

The design management models identified in this research (PDC, 1997; Bruce et al., 1999; Treptow, 2007; Mckelvey; Munslow, 2008; Renfrew; Renfrew, 2009) can be applied to the apparel industry companies. These models were arranged in Table 2 , in such a way that the phases and/or steps correspond to each other. 
Table 2 Comparative of development process in apparel product.

\begin{tabular}{|c|c|c|c|c|c|c|}
\hline CPD (1997) & $\begin{array}{l}\text { Bruce et al. } \\
\text { (1999) }\end{array}$ & $\begin{array}{l}\text { Treptow } \\
(2007)\end{array}$ & $\begin{array}{l}\text { McKelvey } \\
\text { and Munslow } \\
(2008)\end{array}$ & $\begin{array}{l}\text { Renfrew and } \\
\text { Renfrew } \\
\text { (2009) }\end{array}$ & \multicolumn{2}{|c|}{$\begin{array}{l}\text { Adaptation proposed } \\
\text { by the author }\end{array}$} \\
\hline $\begin{array}{l}\text { - Recognition } \\
\text { or impulse }\end{array}$ & $\begin{array}{l}\text { - Taking } \\
\text { action }\end{array}$ & - & $\begin{array}{l}\text { - Briefing } \\
\text { analysis } \\
\text { (opportunitie } \\
\text { s to innovate) }\end{array}$ & $\begin{array}{l}\text { - Market } \\
\text { research }\end{array}$ & $\begin{array}{l}\text { - Creation of } \\
\text { Guidelines }\end{array}$ & \multirow{8}{*}{ 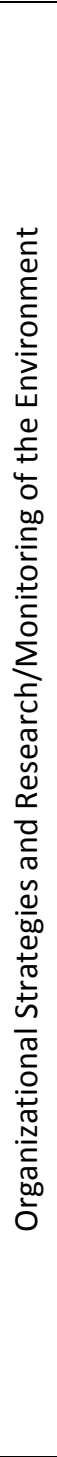 } \\
\hline - Analysis & $\begin{array}{l}\text { - Evaluation of } \\
\text { the concept }\end{array}$ & $\begin{array}{l}\text { - Planning and } \\
\text { Schedule }\end{array}$ & $\begin{array}{l}\text { Inspiration } \\
\text { Research and } \\
\text { Direction } \\
\text { Research }\end{array}$ & $\begin{array}{l}\text { Identification } \\
\text { of the } \\
\text { consumer }\end{array}$ & $\begin{array}{l}\text { - Trend } \\
\text { research }\end{array}$ & \\
\hline $\begin{array}{l}\text { - Definition/ } \\
\text { decision }\end{array}$ & $\begin{array}{l}\text { - Briefing } \\
\text { - Validation of } \\
\text { the briefing }\end{array}$ & $\begin{array}{l}\text { - Briefing } \\
\text { - Concept of the } \\
\text { collection } \\
\text { - Development }\end{array}$ & $\begin{array}{l}\text { - Design } \\
\text { process }\end{array}$ & $\begin{array}{l}\text { - Research } \\
\text { and } \\
\text { development }\end{array}$ & $\begin{array}{l}\text { - Creation of } \\
\text { the collection }\end{array}$ & \\
\hline \multirow[t]{2}{*}{$\begin{array}{l}\text { - Exploration } \\
\text { - Selection }\end{array}$} & $\begin{array}{l}\text { - Mock up } \\
\text { - Mock-ups } \\
\text { (re-worked } \\
\text { and re- } \\
\text { evaluated) }\end{array}$ & - & - Prototyping & - & $\begin{array}{l}\text { - Production of } \\
\text { the template } \\
\text { piece }\end{array}$ & \\
\hline & $\begin{array}{l}\text { - Experimental } \\
\text { production }\end{array}$ & $\begin{array}{l}\text { - Launching and } \\
\text { release }\end{array}$ & - & - & $\begin{array}{l}\text { - Launching and } \\
\text { release }\end{array}$ & \\
\hline $\begin{array}{l}\text { - } \\
\text { Development } \\
\text { - Specification }\end{array}$ & $\begin{array}{l}\text { - Total } \\
\text { production }\end{array}$ & $\begin{array}{l}\text { - Sales and } \\
\text { production }\end{array}$ & - & - & $\begin{array}{l}\text { - Production of } \\
\text { the collection } \\
\text { - Revision and } \\
\text { quality control }\end{array}$ & \\
\hline $\begin{array}{l}\text { - Launching of } \\
\text { the product }\end{array}$ & $\begin{array}{l}\text { - Promotion } \\
\text { of launching }\end{array}$ & - Deliveries & $\begin{array}{l}\text { - Selected } \\
\text { pieces for the } \\
\text { collection } \\
\text { - Promotion }\end{array}$ & $\begin{array}{l}\text { - } \\
\text { Presentation } \\
\text { of the } \\
\text { collection }\end{array}$ & $\begin{array}{l}\text { - Distribution in } \\
\text { the retail } \\
\text { outlets and/or } \\
\text { to } \\
\text { representatives }\end{array}$ & \\
\hline- & $\begin{array}{l}\text { - Evaluation of } \\
\text { the launching } \\
\text { - Removal of } \\
\text { the product } \\
\text { from the } \\
\text { market }\end{array}$ & $\begin{array}{l}\text { - Feedback } \\
\text { meeting }\end{array}$ & - & - & $\begin{array}{l}\text { - Market } \\
\text { monitoring }\end{array}$ & \\
\hline
\end{tabular}

Source: Adapted from CPD (1997), Bruce et al. (1999), Treptow (2007), McKelvey and Munslow (2008), Renfrew and Renfrew (2009).

\subsection{The process of development of a product of apparel companies and the ones involved}

The process of developing apparel pieces, originated from interviews with experts, starts with the guidelines of the collection being created and these guidelines being aligned with the company's strategies. It is noteworthy that designers have to be embedded with the perception of design understood as a value by the company. Bruce et al. (1999) state that designers need information about the projects, as market data, specificities of production, prices, planning, and deadlines to be met for a better alignment with the initial briefing.

From the definition of the guidelines for the new collection and the products, there is the research stage of trends going from the monitoring of the market, the creation of the collection, production of the template pieces, production of the collection, revision and quality control, and distribution of products to the monitoring of consumer satisfaction by the company.

Afterwards, once the productions and distribution of the apparel is concluded, the client will give a feedback, which will be a useful tool for the creators (Borja de Mozota, 2003). These creators often 
as a stylist director or even as a design manager follow three collections simultaneously. The collections fall/winter, spring/summer, and high summer demand this professional to follow three collections in parallel, by monitoring the market's acceptance of the products from the current collection, the production of template pieces to the collection that will come in the following season, and trend research for the collection that will come subsequently. According to Vincent-Ricard (2008), the final product, i.e., the clothing, also presents the particularity of being a consumer object that needs the two-year period to be finalized, from the textile fibber to the provision in the market. However, according to the author, this product is renewed every six months, with constant regularity, presenting a planned obsolescence.

Importantly, according to the adaptation proposed by the author, there is the participation of someone responsible for the design, either the designer or the stylist or the director of the style department, on the steps of the process of development of products reported by the interviewees. It should be noted also that each step requires data, information, and competencies that require the involvement of different individuals, teams, sectors, and raw material and / or services suppliers, as shown in Figure 1, thus comprising multidisciplinary teams.

The presence of a design professional at every stage, whether the stylist or the designer or a director of style, it is necessary to follow-up and monitor the piece throughout the product process of development, having direct or indirect action. Kotler and Rath (1984) corroborate this claim and emphasize that designers participate in all stages of products' development, while interacting with all the areas involved in a particular project. In the definition of the design management, Avendaño (2003) stresses the importance of integrating the different participating agents in the design management and advocates the active participation of designers and others involved in the decisions of products.

This design professional will work directly on the initial steps of creating the design strategies and guidelines for a new collection, on the trend research, and on the creation of the collection. In line with the relevance of the early stages of a project, Kotler and Rath (1984) emphasize that a common and recurrent error in companies is the late entry of designers in a process of development of a new product, or the wrong choice of the type of professional to work in this design stage.

The design professional will also follow the making of the template piece, the production of the collection (modelling, production, monitoring of suppliers), and the final revision and quality control of the pieces produced. This professional will be responsible for transmitting the mood, that is, the concept of the collection to the commercial representatives, sellers, managers, and other individuals working in the retail outlet. The design professional also interact with the other stakeholders who are responsible for each of the productive steps. In the final stage of market monitoring, the design professional goes to the point of sale and monitor social networks or other means for research and feedback, to check the acceptance by the consumers regarding the part produced.

Dinsmore and Silveira Neto (2007) list as the main professionals involved and managed in a project: project manager, responsible by the project, sponsors, clients, project team, functional groups, and outsources. Along with them, in the apparel industry, the suppliers as external agents are found. The complex management of this chain of apparel industry suppliers as well as the exchange of information and knowledge with these agents is characterized by the large number of people involved and therefore requires great flexibility and adaptability to meet the constant market demands. This outsourcing of production is a reflection of a market dynamics and results from a strategy that provides greater flexibility and agility in the manufacturing processes, consolidating production networks in a single organization.

Steps of the process of development of products, such as modelling, part of the production, and distribution can be automatized. However, while the advance in technology has proved an ally to increase production, determining stages of the manufacturing process are still performed manually, as it is the case of embroiders or seamstresses in the manufacture of the template parts. According 
to Brazilian Association of Textile and Clothing Industry - ABIT (2010), this sector, regardless of the technological advances, is still intensive when it comes to work labour. Some companies remove one seamstress from the production line when the template pieces are elaborated. These seamstresses have tacit knowledge that hardly becomes explicit, because there are no records of information or knowledge coming from them. According to Nonaka (1991), tacit knowledge refers to the technical abilities, such as informal and hard-to-be specified skill, that is, the "know-how." The author exemplifies that artisans develop a specific skill in their fingertips, being incapable to explicit the technical principles related to their skill. Other companies have a practice to transfer knowledge and consequent learning among the seamstresses of production lines in their plants, while transforming existing tacit knowledge into new tacit knowledge. Thus and while corroborating the statement by Capaldo (2007), it is shown the relevance of the encouragement to the organizational routines of sharing knowledge.

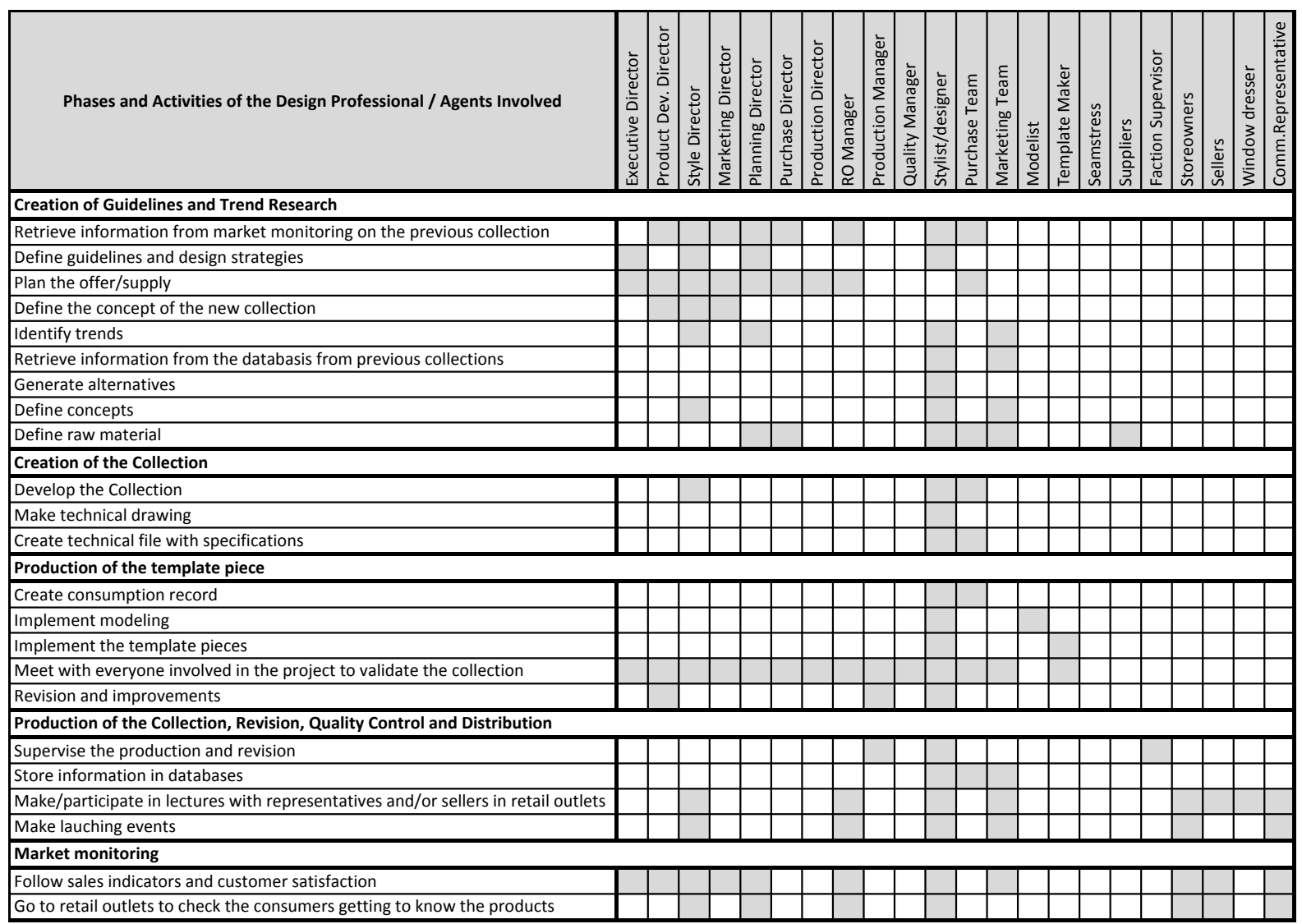

Figure 1 Phases and activities regarding the product to develop apparel pieces and the main involved in the design management of the companies of this industry

\subsection{The determinant moments throughout the process of development of apparel products}

Considering the highlighted topics, the proposition of moments in the process of development of a product determining the design management to occur. Aiming to achieve a differentiation in their products to achieve a sustainable competitive advantage, the apparel industry companies look at the steps of this process, such as:

1. The initial step for defining the strategies and guidelines and for creating the concept for the new collection (Determinant Moment 1 - DM1);

2. The step for researching and identifying trends and grouping of teams with different specializations to discuss and validate the collection (Determinant Moment 2-DM2); 
3. The moment for defining the template pieces to validate and start the production of the collection as well as the registration of drawings and technical files (Determinant Moment 3 - DM3);

4. The step of transmitting the mood, that is, the concept of the new collection to the managers, sellers, and store owners in retail outlets, as well as commercial representatives (Determinant Moment 4-DM4);

5. The market monitoring by both the data analysis and indicators and by direct contact with consumers in retail outlets or in virtual contacts (Determinant Moment 5 - DM5);

6. Moments of creation, exchange, and retention of essential data and information, as well as moments of creation, development, and retention of individual, collective, and organizational competences (DM1, DM2, DM3, DM4, and DM5).

Figure 2 shows determinant moments for the design management to occur and to foster design as a vehicle for change in the process of development of a product of the apparel industry companies.

\begin{tabular}{|c|c|c|c|c|c|c|c|}
\hline $\begin{array}{l}\text { CREATION OF } \\
\text { GUIDELINES } \rightarrow\end{array}$ & $\begin{array}{l}\text { TREND } \\
\text { RESEARCH }\end{array}$ & $\rightarrow \begin{array}{c}\text { CREATION } \\
\text { OF THE } \\
\text { COLLECTION }\end{array}$ & $\rightarrow \begin{array}{c}\text { PRODUCTION } \\
\text { OF THE } \\
\text { PROTOTYPE }\end{array} \rightarrow \begin{array}{c}\text { PRODUCTION } \\
\text { OF THE } \\
\text { COLLECTION }\end{array}$ & $\begin{array}{l}\text { REVISION AND } \\
\text { QUALITY } \\
\text { CONTROL }\end{array}$ & \multicolumn{2}{|c|}{$\begin{array}{l}\text { DISTRIBUTION IN THE } \\
\text { RETAIL OUTLETS AND/ } \\
\text { OR REPRESENTATIVES }\end{array}$} & $\begin{array}{c}\text { MARKET } \\
\text { MONITORING }\end{array}$ \\
\hline DIM1 & \multicolumn{2}{|r|}{ DM2 } & DIR3 & \multicolumn{3}{|c|}{ DMM } & DMS \\
\hline $\begin{array}{l}\text { - Definition of } \\
\text { guidelines and design } \\
\text { strategies } \\
\text { - Definition of the } \\
\text { concept of the new } \\
\text { collection. }\end{array}$ & \multicolumn{2}{|c|}{$\begin{array}{l}\text { - Identification of trends } \\
\text { - Use of databasis from } \\
\text { previous collections } \\
\text { - Generation of alternatives } \\
\text { - Definition of concepts }\end{array}$} & $\begin{array}{l}\text { - Technical drawing } \\
\text { - Technical file with specifications } \\
\text { - Implementation of modeling } \\
\text { - Implementation of template pieces } \\
\text { - Meeting with everyone involved in the } \\
\text { project to validate the collection. }\end{array}$ & \multicolumn{2}{|c|}{$\begin{array}{l}\text { - Store information in } \\
\text { database } \\
\text { - Lectures with } \\
\text { representatives and/or } \\
\text { sellers in sales outlets } \\
\text { - Launching events }\end{array}$} & \multicolumn{2}{|c|}{$\begin{array}{l}\text { - Market monitoring: sales tracking, } \\
\text { sales indicators, and customer } \\
\text { satisfaction } \\
\text { - Going to the sales outlets to check } \\
\text { the consumers getting to know the } \\
\text { products. }\end{array}$} \\
\hline
\end{tabular}

Figure 2 Determinant moments for the design management to occur and actions from this design professional, before the validation from the experts

\subsection{The determinant moments after the validation from the experts}

Regarding the structure of the process of development of products, as illustrated in Figure 2, the interviewees in general understood that it was suitable to the apparel industry and aligned to the dynamics of this market. Nevertheless, it was suggested to insert the step of launching and disseminating in this process, soon after all involved approved the template pieces of the collection. 12 highlighted that "the preparation occurs between the definition of the template pieces and launching and release of the collection in the market." Moreover, the professional mentioned that the time for preparing this material is short and this is why it has to be carefully programmed. The task of communicating and promoting the new collection to the commercial representatives and storeowners happens before their distribution to these agents. However, 14 mentioned, "launching and release can be anticipated to a previous step for major clients, who despite being in small number, strongly impact the collection sales." Therefore, inserting this step in the process of development of products is considered relevant and pertinent.

The comment about inserting the step for launching and releasing the collection led to the proposition of one more determinant moment. The moment inserted was placed between the definition of the template pieces and launching and release of the collection into the market. One action of the design professional related in this determinant moment is the storage of information in databases because of the approval and completion of the template pieces. These updated databases determine how well the collection is doing, whether to provide information to the involved in the process or as a collective memory of the teams and the organization. Other two actions referring to this moment are connected to the following step (launching and release of the collection): lectures with representatives and/or sellers in the retail outlets, and promotional launching events (fashion runways and/or media, such as radio, TV, social networks, and the company's website).

Therefore, determinant moments for the design management and action of the design professional to occur, after checking and evaluation of experts, are shown in Figure 3 and can be listed as follows: 
1. In the initial moment, related to the definition of strategies and guidelines for the concept of the new collection, data and information from the market monitoring performed in the end of the process of the previous collection have to be recovered. Guidelines and design strategies that are aligned to the organizational strategy, culture, and company's values are also defined. Thus, it will be possible to define the planning of the offer and the concept of the new collection, both aligned to the design strategies (Determinant Moment 1-DM1);

2. After researching trends and consulting the database system of the previously developed collections, alternatives are generated and concepts and raw materials are defined to be used for developing the new collection (Determinant Moment 2-DM2);

3. Once the concept and the collection drawings are created, it is the time to detail this creation to produce the template pieces. Technical drawings, data sheet with specifications, consumption record, preparation to make the template piece, and modelling it are made (Determinant Moment 3-DM3);

4. The moment for grouping the teams with different expertise for discussion and collection validation is also considered a major step towards the design management (Determinant Moment 4-DM4);

5. The stage for launching the collection happens through promotional material but also the transmission of the mood, that is, the concept of the new collection to the managers, sellers, and shopkeepers in retail outlets, as well as to commercial representatives. At this time, information that still must be put in the system should also be stored, in order to have a complete data basis, since the details are already closed and the collection is already being put to production (Defining Moment 5 - DM5);

6. The final moment is the market monitoring by both the data analysis and indicators and by direct contact with consumers in retail outlets or in virtual contacts, mapping the acceptance of the products on the market (Determinant Moment 6-DM6);

7. Moments of creation, exchange, and retention of essential data and information, as well as moments of creation, development, and retention of individual, collective, and organizational competences (DM1, DM2, DM3, DM4, DM5, and DM6).

\section{DM1 DM2 DM3 DM4 DM5 DM6}

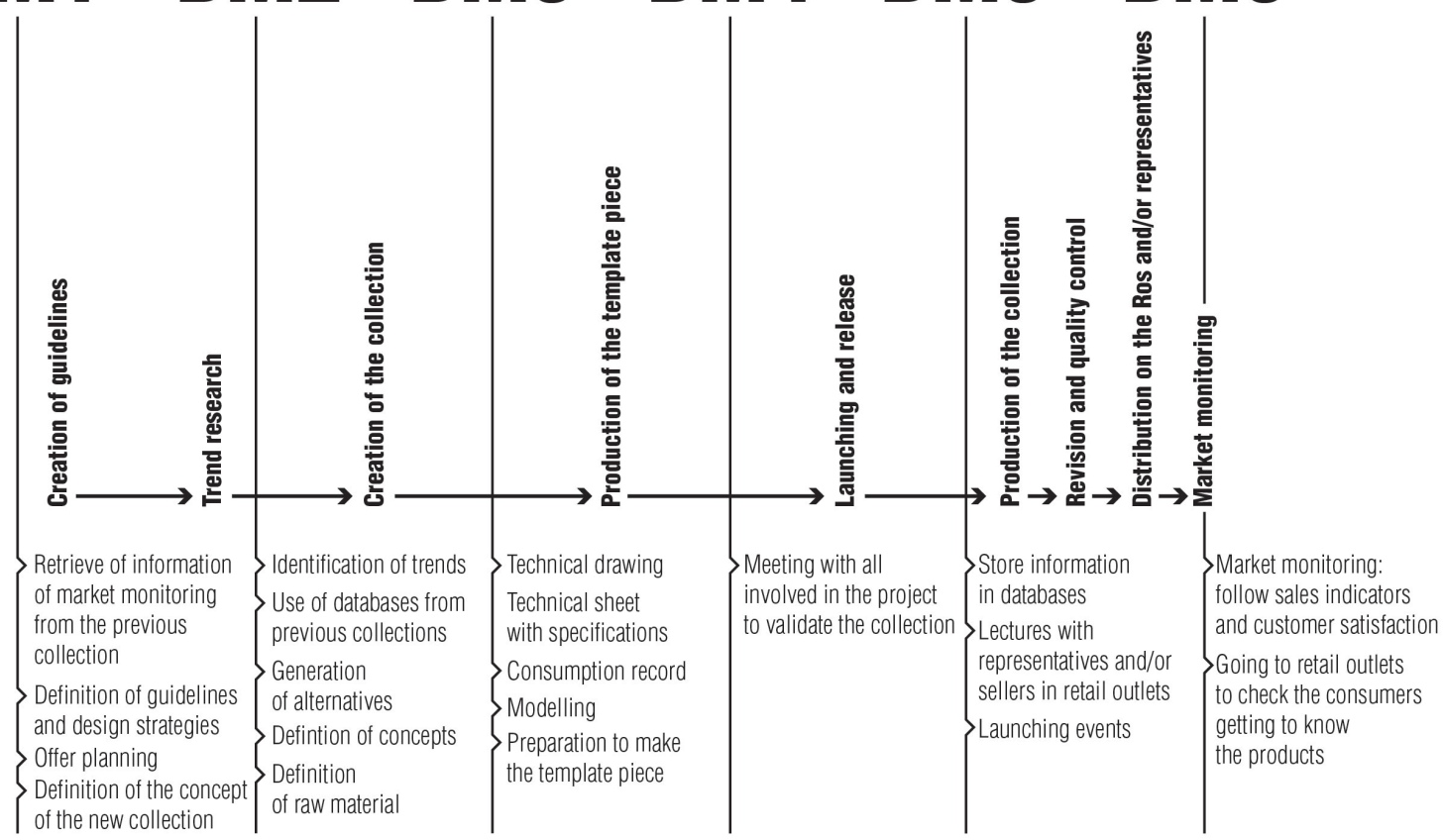

Figure 3 Determinant moments for the design management to occur and action of the design professional 


\section{Conclusions and suggestions for future research}

Thus, this article aims to systematize the process of product development, identifying the players and their competencies involved and mapping the determinant moments for the design management occurrence in context analysis. In the design management of clothing companies, the creation and the occurrence of specific knowledge and information of this sector is clearly perceived, be it from individual practices and routines or from the integration of work teams. Internal arrangements, work routines, and a systematic of processes could help in mapping these occurrences, so that it is possible to manage the activities and resources (tangible and intangible) involved in design management.

Some organizational implications can be mentioned, as a result of determinant moments implementation in the occurrence of design management, such as: the employees' desire to remain with routines and practices already established and rooted in organizations, the conflict between stakeholders and the possible costs increase in the short term due to raising activities and trainings of employees to perform these new activities. However, these implications are supposed to be addressed and settled by managers and directors.

Therefore, it is noteworthy the relevance of identifying determinant moments for the occurrence of design management as well as the ones involved in each step. It will be possible to evaluate the efficiency of the competencies for the design management to occur and to foster design as a vehicle for change. One limitation of this study lies in the fact that sometimes, the product development process has several steps and timelines occurring simultaneously, and that require multiple overlaps of time and events. This research also presents the application of limitation in a heterogeneous sample of companies inserted in the apparel sector, in terms of size, structure and service to the market. For future research, we suggest to conduct a study using a larger sample of companies, or in companies in other regions of Brazil.

\section{References}

ABIT - Brazilian Association of Textile and Clothing Industry. (2010). PRADO, M.V. (org.). Brasil têxtil 2010: relatório setorial da indústria têxtil brasileira. São Paulo, IEMI.

Acklin, C. (2014, 20 Feb 2014). Design management model. Retrieved from http://www.academia.edu/191256/Lucerne_Design_Management_Model.

Alderson, P., Green, S., \& Higgins, J. P. T. (2004). Cochrane reviewers' handbook 4.2.2, Cochrane Library, Issue 1, Chichester: Wiley.

Anderson, L. M., Fielding, J. E., Fullilove, M. T., Scrimshaw, S. C., \& Carande-Kulis, V. G. (2003). Methods for conducting systematic reviews of the evidence of effectiveness and economic efficiency of interventions to promote healthy social environments, American Journal of Preventive Medicine, 24:32-46.

Avendaño, L. E. C. (2002). Resgate do protagonismo do desenhista industrial através da gestão do design. 50 Congresso Internacional de Pesquisa em Design, Rio de Janeiro, Brazil: P\&D.

Bardin, L. (2005). Análise de conteúdo, Lisboa: Edições 70.

Barney, J. B. (1991). Firm resourced and sustained competitive advantage. Journal of Management, 7(1).

Best, K. (2006). Design management: managing design strategy, process and implementation, Switzerland: Ava.

Biolchini, J. C. A.; Mian, P. G.; Natali, A. C. C.; Conte, T. U. \& Travassos, G. H. (2007). Scientific research ontology to support systematic review in software engineering. Advanced Engineering Informatics, 21, 133-151.

Borja de Mozota, B. (2003). Design management: using design to build brand value and corporate innovation. New York: Allworth.

Bruce, M., Cooper, R., \& Vazquez, D. (1999). Effective design management for small businesses, Design Studies, 20(3), 297-315. 
Capaldo, A. (2007). "Network structure and innovation: the leveraging of a dual network as a distinctive relational capability", Strategic Management Journal, 28, 585-608.

Dinsmore, P. C., \& Silveira Neto, F. H. (2007). Gerenciamento de projetos e o fator humano: conquistando resultados através de pessoas, Qualitymark, Rio de Janeiro.

Kotler, P., \& Rath, G. A. (1984). Design: A Powerful but neglected strategic tool, Journal of Business Strategy, 01.

Malhotra, N. (2012). Pesquisa de marketing: uma orientação aplicada. Porto Alegre: Bookman.

Mckelvey, K., \& Munslow, J. (2008). Fashion design: process, innovation and practice. New York: Blackwell Science.

Michaux V. (2009). Articuler les compétences individuelle, collective, organisationnelle et stratégique: les éclairages de la théorie des ressources et du capital social. In: Retour D., Picq T., Defelix C. (eds). Gestion des compétences: Nouvelles relations nouvelles dimensions. Paris: Vuibert - AGRH Gracco CNRS, 13-33.

Nelson, R. R., \& Winter, S. G. (1982). An Evolutionary theory of economic change. Cambridge: Belknap Press of Harvard University Press.

Nonaka, I. (1991). The knowledge-creating company. Harvard Business Review. 69(6), 96-104.

PDC - Portuguese Design Centre (1997). Manual de gestão do design. Porto: PDC.

Pereira, D. (2009). Competências da gestão estratégica do design no pólo moveleiro do Alto Vale do Rio Negro (SC). Dissertation. Universidade Técnica Federal do Paraná, Ponta Grossa, PR.

PMBOK - Project Management Institute (2000). A Guide to the project management body of knowledge, PMBOK. PMI.

Renfrew, C., \& Renfrew, E. (2009). Developing a collection. Lausanne: Ava Publishing.

Silva, C. H. (2009). Balanced scorecard como ferramenta para gestão estratégica de design, Dissertation Universidade Federal de Santa Catarina, Florianópolis, SC.

Slack, N., Chambers, S., Johnston, R., \& Betts, A. (2012). Operations and process management: principles and practice for strategic impact. New York: Prentice Hall.

SVID - Swedish Industrial Design Foundation. (2014, 03 Jan 2014). 10 points: Attitudes, profitability and design maturity in Swedish companies. Retrieved from: http://www.svid.se/upload/SVID_2011/For_foretag/Undersokningar/Folder_10_points.pdf.

Treptow, D. (2007). Inventando moda: planejamento de coleção. Brusque: D. Treptow.

Valle, A. B., Soares C. A. P., Finocchio, J. J., \& Silva, L. S. F. (2007). Fundamentos do gerenciamento de projetos. Rio de Janeiro: FGV.

Vincent-Ricard, F. (2008). As espirais da moda. Rio de Janeiro: Paz e Terra.

Wernerfelt, B. (1984). A Resource-based view of a firm. Strategic Management Journal, 05.

About the Authors:

Cláudia de Souza Libânio is Doctor in engineering production. She is a full-time professor at UFCSPA/Brazil. Her research studies focus on strategic design and design management. She also develops studies in healthcare sector and garment industry.

Fernando Gonçalves Amaral is PhD in ergonomics. He is a full-time professor at UFRGS/Brazil. His research studies focus on design management, ergonomics and health and occupational safety.

Sérgio Almeida Migowski is Doctor in business administration. He is a full-time professor at IFRS/Brazil. Has 30-year professional experience in the private sector in service provider organizations. His areas of interest are hospital management and design management in healthcare. 